\title{
Recent advances in therapeutic applications of neutralizing antibodies for virus infections: an overview
}

\author{
Manasik Gumah Ali ${ }^{1} \cdot$ Zhening Zhang $^{1} \cdot$ Qi Gao ${ }^{1} \cdot$ Mingzhu Pan ${ }^{1} \cdot$ Edward G Rowan ${ }^{2} \cdot$ Juan Zhang ${ }^{1} \mathbb{C}$
}

Received: 28 May 2020 / Accepted: 21 October 2020 / Published online: 8 November 2020

(C) Springer Science+Business Media, LLC, part of Springer Nature 2020

\begin{abstract}
Antibodies are considered as an excellent foundation to neutralize pathogens and as highly specific therapeutic agents. Antibodies are generated in response to a vaccine but little use as immunotherapy to combat virus infections. A new generation of broadly cross-reactive and highly potent antibodies has led to a unique chance for them to be used as a medical intervention. Neutralizing antibodies (monoclonal and polyclonal antibodies) are desirable for pharmaceutical products because of their ability to target specific epitopes with their variable domains by precise neutralization mechanisms. The isolation of neutralizing antiviral antibodies has been achieved by Phage displayed antibody libraries, transgenic mice, B cell approaches, and hybridoma technology. Antibody engineering technologies have led to efficacy improvements, to further boost antibody in vivo activities. "Although neutralizing antiviral antibodies have some limitations that hinder their full development as therapeutic agents, the potential for prevention and treatment of infections, including a range of viruses (HIV, Ebola, MERS-COV, CHIKV, SARS$\mathrm{CoV}$, and SARS-CoV2), are being actively pursued in human clinical trials."
\end{abstract}

Keywords Humoral immune response Epitope $\cdot$ Neutralizing antibodies $\cdot$ Monoclonal Polyclonal $\cdot$ Phage display · Glycoprotein

$\begin{array}{ll}\text { Abbreviations } \\ \text { NAbs } & \text { Neutralizing antibodies } \\ \text { bNAbs } & \text { Broadly neutralizing antibodies } \\ \text { mAb } & \text { Monoclonal antibodies } \\ \text { CDC } & \text { Complement-dependent cellular cytotoxicity } \\ \text { ADCP } & \text { Antibody-dependent cellular phagocytosis } \\ \text { ADCC } & \text { Antibody-dependent cellular cytotoxicity } \\ \text { NHPs } & \text { Non-human primates } \\ \text { GP } & \text { Glycoprotein } \\ \text { RBD } & \text { Receptor-binding domain } \\ \text { DPP4 } & \text { Receptor dipeptidyl peptidase4 } \\ \text { ART } & \text { Anti-retroviral therapy } \\ \text { Fc } & \text { Fragment crystallizable domain } \\ \text { Fab } & \text { Fragment of antigen-binding }\end{array}$

Juan Zhang

zhangjuan@cpu.edu.cn

1 Antibody Engineering Laboratory, School of Life Science \& Technology, China Pharmaceutical University, Nanjing, China

2 Strathclyde Institute of Pharmacy and Biomedical Sciences, University Strathclyde, Glasgow, UK
CDRs Complementarity determining regions

ACE2 receptor - angiotensin-converting enzyme II

\section{Introduction}

An antibody is a protective protein produced by the immune system in response to the detection of foreign material known as antigen [1]. In 1890 Emil von Behring and Shibasaburo Kitasato discovered antibodies as protective antitoxins in the blood of animals exposed to diphtheria or tetanus toxin [2]. To date, antitoxins are still in use as a preventive and treatment option for some infections [3]. Antibodies have been a significant research subject due to their crucial role in adaptive immunity and their wide range of specificities [4]. Although vaccines aim to induce immune response in host cells to produce antibodies, the high rate of genetic mutation in viral strains increases the virus' possibility of reactivation(due to loss of antibody specificity), which can lead to ineffective vaccination as in the case of HIV-1 [5, 6].

Antibodies have been used for the development of vaccines with little use as biological therapy to combat viral infections $[7,8]$. A new generation of broadly cross-reactive and highly 
potent antibodies has led to a unique chance for intervention [9]. Antibodies are desirable for pharmaceutical products because of their ability to target specific epitopes with their variable domains.

An antiviral antibody is a unique research discovery used by virologists to better understand the exact mechanisms of binding and entering of viruses into hosts and their antiviral immunity. Based on the mechanisms of action, antiviral antibodies can be categorized into neutralizing and nonneutralizing antibodies. Neutralizing antibodies act by binding to a specific epitope on the viral envelope and lead to neutralization of the virus infection by several mechanisms which have been mentioned in details in this review, notably neutralizing antibodies have shown great advances in clinical trials targeting many viruses. In non-neutralizing antibodies, the antibody bind to an area on the surface of the virus without neutralizing the infection or total removal of viral titer. As the antibody does not block infection, the whole virus-antibody complex enters the cell via endocytosis. Then other nonneutralizing humoral effector functions perform as antibodydependent cell-mediated cytotoxicity (ADCC) or antibodymediated phagocytosis, aggregation, and even immune activation [10-13].

The versatility of therapeutic antibodies to combat cancer, autoimmune diseases and passive antibody therapies for infectious diseases have been reviewed in the past $[8,14,15]$; however, this review article mainly focuses on recent advancements in the use of neutralizing antibodies as an established therapeutic antiviral treatment in humans including how antibodies neutralize viruses, their clinical applications, isolation of potent and broadly neutralizing antiviral antibodies, and the limitations of neutralizing antiviral antibodies.

\section{Neutralizing antibodies (NAbs)}

A neutralizing antibody $(N A b)$ is an antibody that protects the host cell from pathogens by neutralizing or inhibiting its biological effect. It blocks interactions of the viral envelope with the host cell receptor or inhibits the release of the viral genome. NAbs that emerge under different constraints are sentinels that provide a better understanding of the humoral immune responses, as well as great insight for the future development of immunotherapeutics [16].

NAbs are the foundation for successful disease prevention; nevertheless, for critical chronic infections such as HCV and $\mathrm{HIV}$, the use of potent and broad NAbs from recombinant vaccines is incomplete $[17,18]$. NAbs can inhibit multiple strains of a particular virus; next to vaccination, neutralizing antibodies gives the best protection against viral infections rather than anti-retroviral therapy ART $[19,20]$.

\section{Monoclonal antibodies(mAbs)}

Monoclonal antibody $(m A b)$ has one type of immunoglobulin with defined specificity and a single isotype [21]. These types of antibodies are used clinically against particular antigens and exhibit therapeutic effects via the antigen-binding fragment $(F a b)$.

Recently, in the Europe and the USA, about 80 monoclonal antibodies have been approved and several hundred of them in clinical trials. In the last decade and a large number of antibodies have been engineered, including novel antibody-like scaffolds, antibody-drug conjugates, and bispecific antibodies [22]. Recently, developed isolation technology produces humanized mAbs from immune and non-immune sources, and that has made distinctive progress in using antibodies for treatment [23].

Antiviral $\mathrm{mAb}$ has been considered as a new immunotherapy treatment to eradicate the outbreak of chronic infections [9]. Antiviral mAbs have characteristic features which include:

a) Ability to target specific epitopes

b) Highly specific

c) High potency

d) Minimal side effect in clinical applications, which enables and encourages large scale production

\section{Polyclonal antibodies}

Polyclonal antibodies are a diverse group of antibodies that target numerous epitopes on the viral envelope during the infection and provide vigorous neutralizing activity [24]. The ability of polyclonal antibodies to target multiple epitopes enables them to trigger a range of effector functions such as steric hindrance (prevent antibody- virus complex from attaching the host surface), aggregation (binding of antibodies to many viruses lead to clearance them from circulation), opsonization (activation of phagocytes cells), and activation of the complement system [25]. There are several advantages of polyclonal antibodies over monoclonal antibodies; low cost and a short production period, they are highly stable and with high affinity; besides, polyclonal antibodies are less sensitive to antigen changes than monoclonal antibodies. In contrast, due to their lack of specificity and a high degree of crossreactivity of polyclonal antibodies, it has limited their use in the clinic [26].

\section{Techniques for isolation of neutralizing antiviral antibodies}

During viral infection in humans, there is a natural immune response toward the virus, which activates innate and humoral 
immune cells to produce B cells. These B cells then produce antibodies to attack the virus.

Various approved strategies have been used to isolate and purify antibodies with specific characteristics and proper function.

\section{Phage displayed antibody libraries}

Phage display is a modern technique of using bacteriophage (viruses that infect bacteria) to express a unique protein variant (such as antibody fragments).

In phage display, a gene encoding a protein of interest is inserted into a phage, causing the phage to display the protein on the outside while containing the gene with the protein on the inside, resulting in a connection between genotype and phenotype [27].

Phage display begins with the amplification of the heavy and light chain gene of the target antibody and the construction of a recombinant phage display plasmid called phagemid. Once bacteria are co-infected with phagemids and helper phages, the phagemid will be replicated, translated, and assembled into infective phages with the target monoclonal antibody fragment displayed on the surface.

Phage display is further used to screen and select the antibody with unique properties, that is, phage-antibody library technology [28]. This process begins with antibody library preparations, followed by ligation of the variable heavy and variable light PCR products into phagemids. Analysis of the clone's monoclonal antibodies is then performed (Fig. 1a).

A vast antibody library and efficient selection are needed to isolate specific monoclonal antibody from the cloned immunoglobulin repertoire. The library is screened for phage binding to an antigen through a surface monoclonal antibody biotechnique, called biopanning. Multiple rounds of phage binding to antigen, washing, elution, and propagation of the phage binders are to be done. During each round, specific binders are selected out from the pool by washing away non-binders and selectively eluting the binding phage clones. After 3 or 4 rounds, the highly particular binding of phage clones through the surface map is characteristic for directed selection on the immobilized antigen (Fig. 1a). This technique has been applied for isolating neutralizing antibodies that have the potential for a range of viruses(severe acute respiratory syndrome (SARS), Ebola virus, yellow fever virus, hepatitis $\mathrm{C}$ virus, measles virus, rabies virus, and influenza virus [24, 27]. Moreover, using yeast phage display technology has led to producing novel mAb against HIV-1 [29].

\section{Transgenic mice technique}

This technique requires the cloning of human mAbexpressing B cells. A human mini-immunoglobulin gene locus is knocked-in into a transgenic mouse (Fig. 1b). The human $\mathrm{mAb}$-expressing $\mathrm{B}$ cells are then isolated from the immunized transgenic mouse and cloned [30]. The process begins with injecting the desired antigen into mice; until the mice develop an immune response, then, the isolated Blymphocytes from mice's spleen are fused with a myeloma cell line, which leads to producing immortalized B cellmyeloma hybridomas. The antibodies that are produced are then screened for the desired $\mathrm{mAb}$ [31].

Antiviral antibodies against rabies and acute respiratory syndrome coronavirus (SARS-CoV) have been successfully isolated by using this technology [32, 33]. Furthermore, the isolation of ( $5 \mathrm{~F} 10$ and $8 \mathrm{~B} 10) \mathrm{mAbs}$ showed broad neutralization against CHIKV infection in vitro [34], and the 20 heterosubtypic mAbs showed promising results in neutralizing influenza virus [35].

\section{Single B cell technique}

This isolation technique can be performed either in an antigenselective manner from peripheral blood or in a random way [36]. Depending on the transformation method, Memory B cells collected from the blood of patients recuperating from viral infection are transformed with Epstein-Barr virus (EBV) and polyclonal memory B cell-activating elements, such as irradiated mononuclear cells and $\mathrm{CpG}$ oligonucleotides (Fig. 1c) These activating elements are TLR4 (Toll-like receptor 4) ligands with immense transformation efficiency [37]. Production of NAbs can be from B memory cells and plasma of non-human primate (NHP) [38-40]. For example, NAbs that have been produced from memory B cells are isolated from persons recovering from dengue and H1N1 influenza infections [41-43].

\section{Hybridoma technology and humanization}

The hybridoma is the most conventional technique for producing therapeutic antibodies from non-human sources. However, a further process called humanization is required.

In the mid-1970s, the discovery of hybridoma technology by César-Milstein's group led to the isolation of monoclonal antibodies from mice that had distinct properties and neutralization capacity [44].

Humanization occurred by grafting complementarity determining regions (CDRs) that determine the binding site of the antibody. The appropriate framework region of the variable domains of a rodent donor $\mathrm{mAb}$ is grafted onto acceptor human antibody frameworks (Fig. 1d). It can reserve the specificity and binding affinity of the mAb with a low risk of immunogenicity.

Smart antibody-screening methods and proper selection of human donors lead to advanced isolation of rare, broadly (NAbs) for several viruses. 
a Micriobio surface display

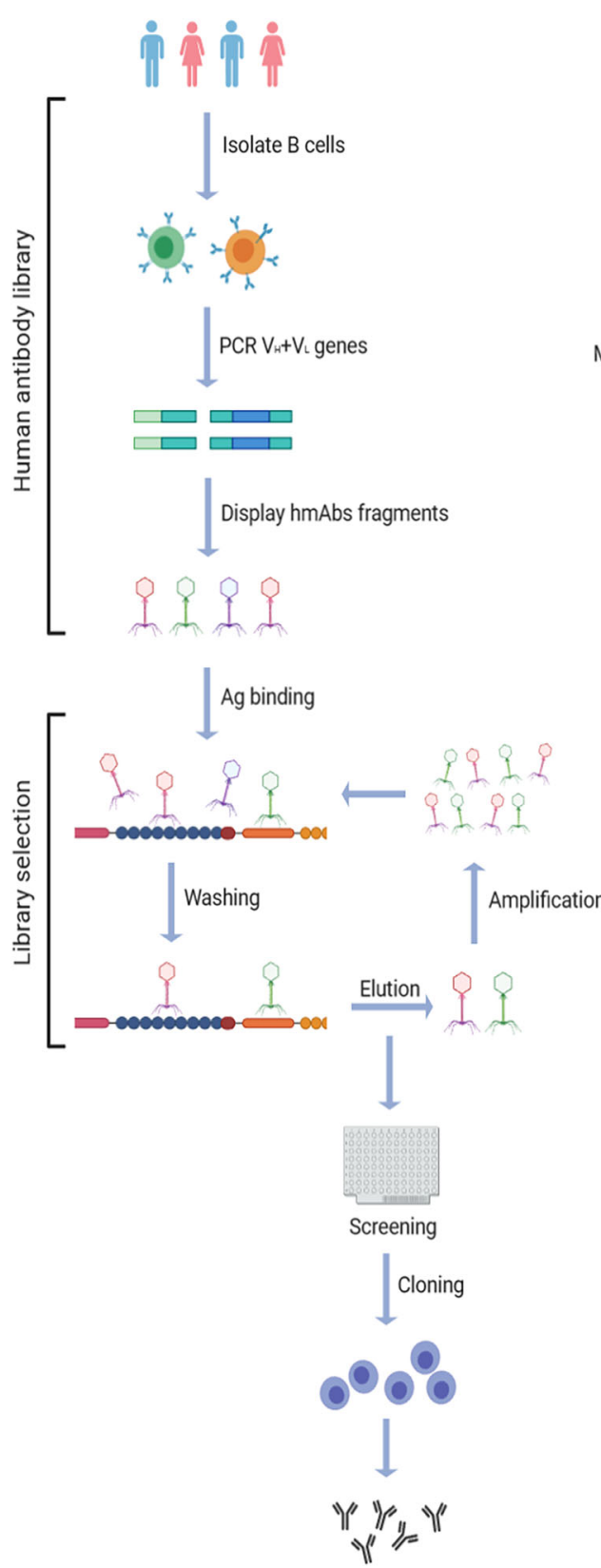

b Transgenic mouse

C Human memory B-cell immortalization

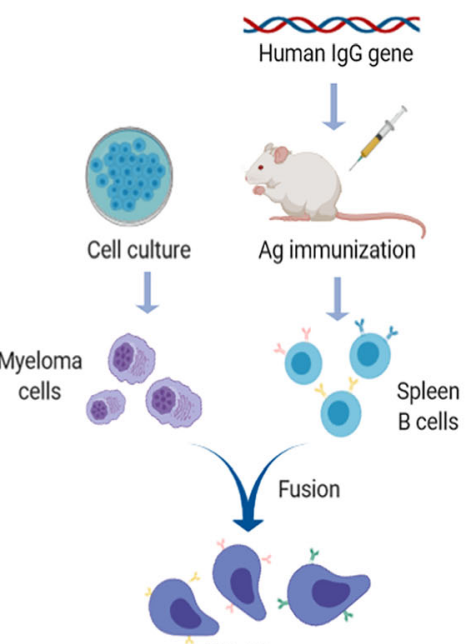

Hybridoma

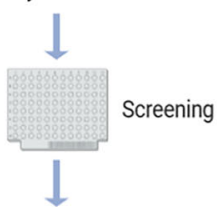

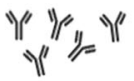

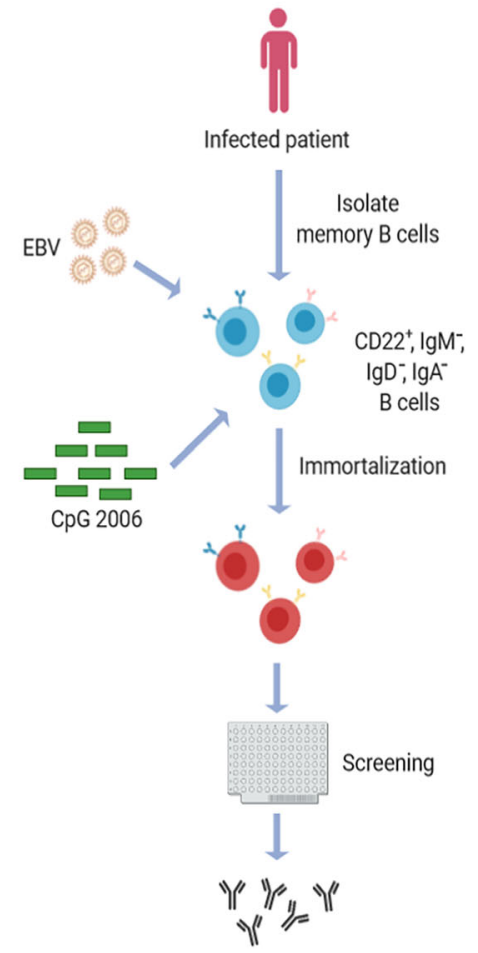

d Humanization

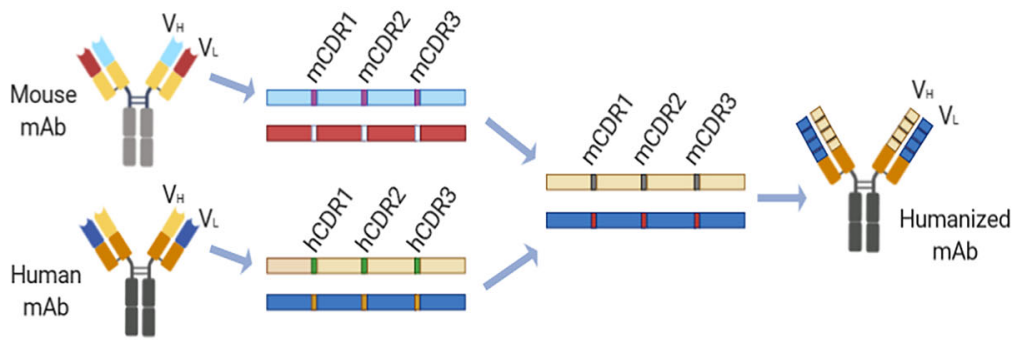

Fig. 1 Techniques for isolation of antiviral antibodies. (a) Phage display library: isolation of antibody from B cells followed by PCR amplification of heavy and light chain genes of antibody. Phagemid is constructed, replicated, translated, and assembled into infective phages. They are then screened to select the desired antibody to clone for more antibodies production and washed undesired antibody. (b) Transgenic mice: A human gene locus knocked-in into an immunized transgenic mouse. B cell is harvested from mice and fused with a myeloma cell line

\section{Mode of viral neutralization}

Viral neutralization is a process by which antibodies prevent viral infection $[45,46]$.

Enveloped viruses enter the host cell by attachment to the host cell surface receptor. In contrast, non- to produce the humanized antibodies. (c) Single B cell technique: isolated $\mathrm{B}$ cell from infected patients transformed with Epstein-Barr virus (EBV) and polyclonal memory B cell-activating elements (irradiated mononuclear cells and $\mathrm{CpG}$ oligonucleotides), then screened to select the desired antibodies. (d) Humanization: complementarity determining regions (CDRs) graft with the appropriate framework region of the variable domains, then transferred into acceptor human antibody frameworks to produce the desired antibody

enveloped viruses enter via lysis of the host cell membrane or making pore-like structures in the membrane. The fusion of virus (enveloped/non-enveloped) with host cell membrane needs particular conformational changes in the viral protein that can be triggered by low $\mathrm{pH}$ in endosomes [47]. 
Table 1 Targets for antibodies on enveloped viruses

\begin{tabular}{|c|c|c|c|c|c|}
\hline Glycoprotein & HIV & Ebola & Influenza & CHIKV & $\begin{array}{l}\text { MERS- } \\
\text { CoV }\end{array}$ \\
\hline Viral spike & Envelope (env) & Glycoprotein & Hemagglutinin (HA) & Glycoprotein & spike \\
\hline Receptor binding domain & Gp120 & GP1 & HA1 & $\mathrm{Fc} \gamma \mathrm{r}$ & $\mathrm{RBD}$ \\
\hline Fusion domain & Gp41 & GP2 & HA2 & $\mathrm{C} 1 \mathrm{q}, \mathrm{Fc} \gamma \mathrm{r}$ & DPP4 \\
\hline
\end{tabular}

This table shows the epitopes on glycoprotein envelope viral spike, the binding domain region required for entering the host cell, and the fusion binding domain that required in the fusion of the virus into the host cell. All of these can be a good target for antibodies to neutralize a group of viruses.

Antibodies selectively bind to specific epitopes on the target antigen either by their variable or constant regions $[48,49]$ (Table 1). There are various mechanisms by which therapeutic antiviral antibodies function to neutralize viruses [24, 27]. Antibodies neutralize viruses either at the virus entry point or the post binding stage.

\section{Inhibition of virus entry into host cells}

Viruses are neutralized in two ways at the stage. The antibody variable domain binds to epitopes on the viral glycoprotein envelope (Fig. 2a), or antibody through the interaction of fab region binds to $\mathrm{Fc} \gamma \mathrm{Rs}$ receptor or coreceptor on the host

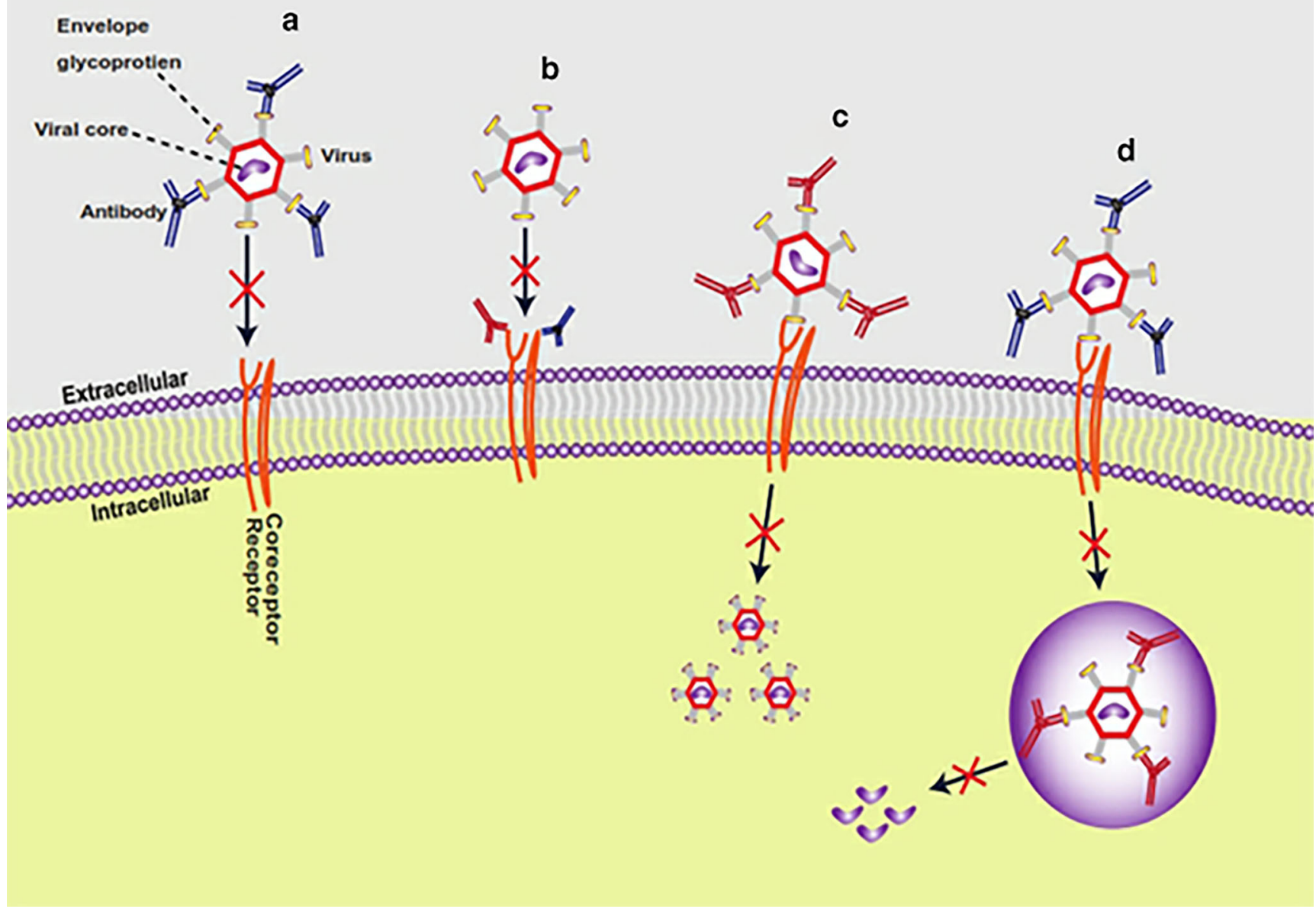

Fig. 2 Modes of viral neutralization. Antibodies neutralize viruses by several mechanisms, either inhibition of virus entry into host cells as (a) Antibodies bind to an epitope in the viral glycoprotein envelope, lead to inhibit attachment to host cells. (b) Antibodies through the fab region can bind to host cell receptors or coreceptors (have Fc $\gamma \mathrm{r}$ )) lead to inhibit viral entry. Or post binding inhibition of antibody-virus complex as (c) antibodies can bind to a non-binding region in the virus envelope lead to inhibit the conformational change to allow membrane fusion. (d) for certain viruses that need low endosomal PH for conformational change, antibodies bind to viral inside the endosome lead to inhibit the change in $\mathrm{PH}$ to achieve the membrane fusion, and antibodies can inhibit the release of the viral virion 
surface membrane (Fig. 2b). Recently the development of multi-antigen region binding to therapeutic antibodies enhances their neutralization potency [41].

\section{Post binding inhibition of antibody-virus complex}

The post binding inhibition of viruses occurs in three forms. In some viruses, binding of the antibody to the non-binding region on the virus envelope inhibits conformational changes required for membrane fusion [50], as illustrated in Fig. 2c. In the case of viruses that require low $\mathrm{pH}$ in endosomes for conformational changes to trigger viral membrane fusion, the binding of the antibody to the virus inhibits the conformational changes necessary for membrane fusion (Fig. 2d). Also, the antibodies can inhibit viral production by detecting the virion in order not to assemble its genetic material with that of the host cell. All of these mechanisms may not happen with a single virus type. It varies from virus to virus, depending on the viral glycoprotein structure. Perhaps significant neutralization effects of antiviral antibodies are mostly attained by blocking viral entry into the host. In some instances, viruses tend to escape neutralizing antibody responses. However, the Fc fragments of monoclonal antibodies can bind to the immune cells to perform further neutralization activities, such as clearing of circulatory viruses, activate cytotoxic killing or phagocytosis of the infected cell, and even induce activation of host immune responses in vivo (Fig. 3) These further activities happen via antibody-dependent cellular phagocytosis $(A D C P)$ and antibody-dependent cellular cytotoxicity $(A D C C)$. It includes the interaction of the Fc (fragment crystallizable domain) of an antibody with its $\mathrm{Fc} \gamma$ receptors $(F c \gamma R s)$ present on immune cell surfaces [6] $[14,51]$.Studies on the functional and molecular properties of monoclonal antiviral antibodies give

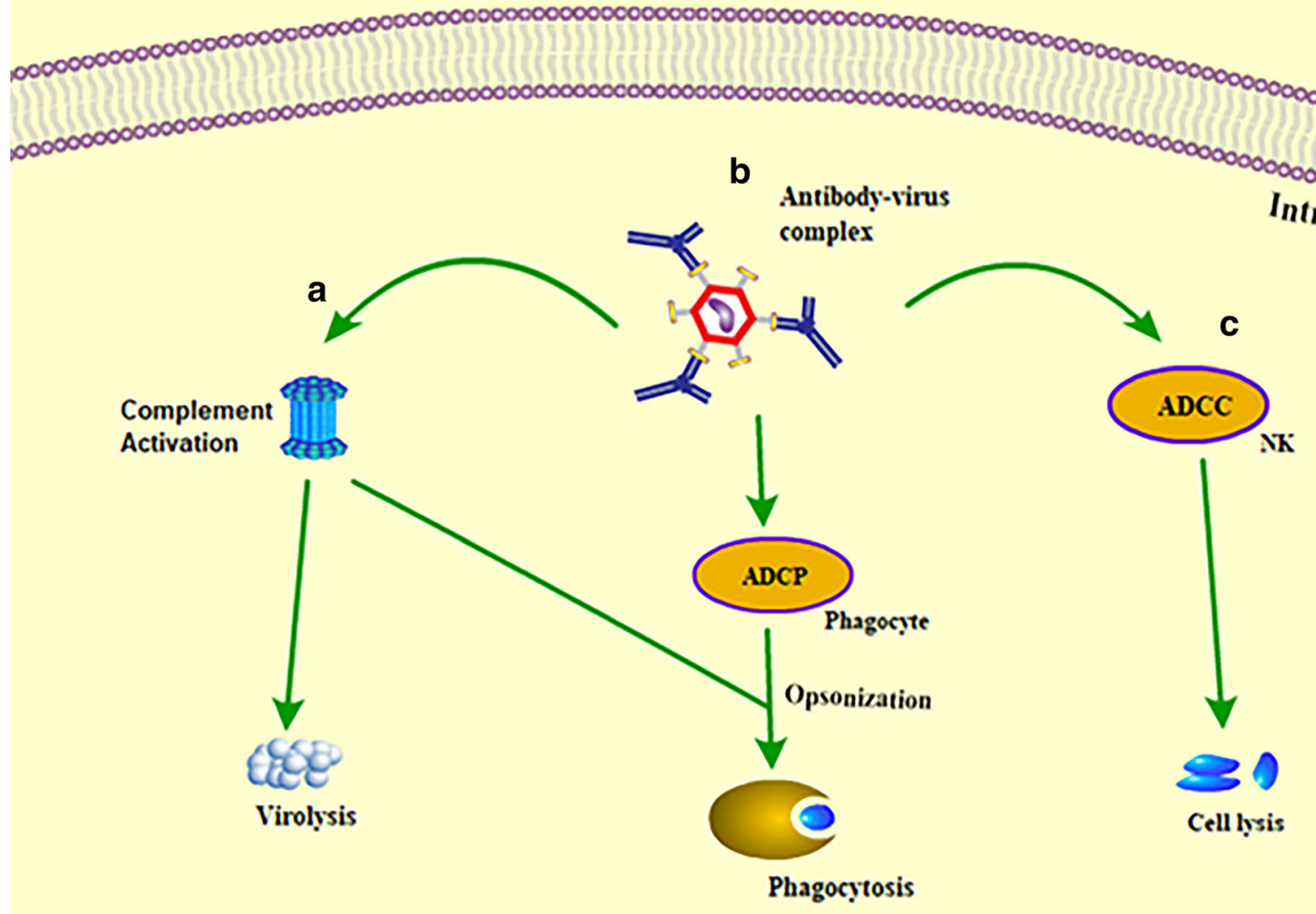

Fig. 3 The antiviral mechanism through antibody FC fragment. The Fc fragments of antibodies bind to the immune cells to perform neutralization activities. (a) Binding of complement to antibody activates complement-mediated virolysis and activation of phagocytosis. (b) Binding of antibodies to a phagocyte ( $\mathrm{Fc} \gamma \mathrm{r}$ ) via antibody-dependent cellular phagocytosis (ADCP) opsonizes the infected cell. (c) Antibodies bind to natural killer (NK) cells via antibody-dependent cellular cytotoxicity (ADCC) to lyse the infected cells 
excellent prospects to recognize epitopes and target antigens as a fundamental strategy for the development of human vaccines and novel immunotherapy [52].

\section{Synergistic effects of neutralizing antiviral antibodies}

Presently, there are no approved combinational antiviral antibodies for the prevention or control of many viral infections in humans. On the contrary, there are several prospective combinational therapies for various kinds of viral infections undergoing trials (Table2). The potency of therapeutic antibodies can be enhanced by multiple antibody engineering technologies. Some of these technologies include the combination of two or more mAbs, the synergy between antiviral drugs and $\mathrm{mAbs}$, and the vector-based delivery of antibodies.

A combination of $\mathrm{mAbs}$ shows high neutralizing activity more than that of individual mAbs. Research on Hepatitis B virus and Respiratory syncytial virus shows the neutralization potential of mAb cocktails (a combination of two or more mAbs) [53]. The synergistic ability of antiviral drugs with mAbs has allowed researchers to explore modes of treatment and routes for administration in certain viruses such as influenza [54]. As in the case of CHIKV virus, using a combination of CTLA4-Ig and antiviral antibody therapy can control severe CHIKV disease and arthritis and might be a great candidate for testing in humans [55]. The vector-based delivery of genes encoding antibody molecules is another synergy that increases neutralization activity. Transgenic mice gained full protection against HCV viral infection when treated with Adeno-associated viral vectors in combination with three bNAbs (AR4A, AR3A, and AR3B) [56].

Drugs can be coupled to antibodies via chemically stable linkers or by direct chemical bonding. Immunological and pharmacological principles determine the effective delivery of antibody-conjugated antiviral drugs. The antibody should be highly specific for a target site, and an adequate number of drug molecules should reach the target to exert their pharmacological effects. Regardless of the mode of coupling, drugantibody complexes are internalized either by passive diffusion or by some active transport mechanism. Complexes internalized in pinocytic vesicles, ultimately, are digested by lysosomal enzymes that cleave the pharmacologically active drug from the antibody. The second mechanism of cell delivery is by the extracellular release of the drug on the surface of specific target cells.

\section{Clinical applications of neutralizing antiviral antibodies}

Anti-retroviral therapies (ARTS) are mostly used for the treatment and prevention of viral infections. Nevertheless, discontinuous administration of ARTs can lead to rebound viremia in patients, consequently making the use of ARTs a lifelong treatment. Currently, research suggests that the use of antiviral antibodies is the best alternative to substitute ART because they have the ability to clear circulatory viruses and boost the immune system to prevent viral infections $[57,58]$.

Unlike the use of antibodies in the treatment of cancer and autoimmune diseases, palivizumab is the only approved antiviral antibody for treating RSV [59].

NAbs show great response toward acute viral infections such as chikungunya virus, Measles virus, and poliovirus due to no evidence of viral escape from the antibody response. While in the chronic infections such as infleunza, Ebola, HIV and Lassa virus; The expression of conserved epitopes wherein the neutralization of viruses occurs $[15,60,61]$, remains insignificant, due to high mutation in some viral strains $[62,63]$.

Here, the recent updates on the development of some antiviral antibodies and their successful applications to fight viral infections are going to be discussed.

\section{NAbs against HIV1}

In 1989, CD4-Fc-fusion was the first antibody used to target HIV. The effectiveness of CD4-Fc-fusion proteins has been widely investigated since its use. Currently, a couple of successful treatments have emerged, and it is on the verge of commercialization [64] with enhanced efficacy and safety. These promising results have broadened and encouraged research into the development of vaccines and immunotherapy [65].

Since a competent and safe HIV-1 vaccine is presently not forthcoming, new advances are required to avoid HIV infection [66]. Isolation of bNAbs with high levels of HIV-1 neutralizing activity from HIV-infected individuals is a further advancement to prevent HIV transfection [67-69]. The HIV1 glycoprotein envelope (ENV) is the main target for NAbs. The ENV can be present on the viral surface in two forms, open or closed conformations with multiple epitopes such as $\mathrm{V} 2$ region, V3 region, CD4 binding site, MPER, and CD20 [70]. Certain groups of HIV-1-infected patients produce a vast and potent HIV-1 neutralizing antibodies ( $b N A b s)$ that, when administered in other hosts like mice or macaques, produce excellent results regarding treatment or prevention of infection. Moreover, many bNAbs typically fail to neutralize coexisting autologous viruses due to antibody-mediated selection against sensitive viral strains [71-73].

For instance, PGDM1400 and CAP256-VRC26.25, which are V2-specific antibodies, have exhibited impeccable neutralization against HIV-1 [74]. Moreover, a high neutralization effect is shown against nonoverlapping sites on the HIV-1 envelope as a CD4-binding site (56) [75, 76], and (V3) region is targeted by BG18 antibody (61) [77]. Besides, there have been promising outcomes of neutralizing 
antibodies targeting the CD4 binding site and $\mathrm{V} 3$ region in preclinical studies, and they showed excellent results protecting rhesus macaques against simian-human immunodeficiency virus (SHIV) [78, 79].

The activation of bNAbs toward the membrane-proximal external region (MPER) has exhibited excellent neutralization breadth. The MPER is a highly conserved region within the type-1 HIV-1 glycoprotein envelope (ENV), which is naturally targeted by bNAbs and aids in membrane fusion [80].

Furthermore, the neutralization breadth of bNAbs happens when $\mathrm{Fc}$ domain of the antibody that binds to Fc $\gamma$ Rs of host cell contributes substantially to block viral entry, suppress viremia, and enhance the protection of host cell in vivo. These results expose the crucial role of $\mathrm{Fc}$ effector in the activity of HIV-1 bNAbs in vivo and provide strategies for developing bNAbs with improved efficacy [81, 82]. Most of the newly discovered HIV mAbs is tenfold more potent than the previous ones. PG9, PG16, and VRC01 bNAbs are 100fold more potent than previous HIV bNAbs [70, 71].

Among many studies that have been reported, promising clinical outcomes using antibodies with broad and potent activity in neutralizing HIV $[83,84]$ such as the anti-CD20 $\mathrm{mAb}$, Rituximab that induces killing of the infected cell, which leads to reduce the pool of HIV-expressing cells when combined with latency reversal agents [85].

\section{NAbs against Ebola virus (EBOV)}

Ebola virus is a Filoviridae that causes severe hemorrhagic fever in humans with enormous public health concerns due to its high transmission and virulence [86]. Since its discovery, it has infected people from various parts of the world, with recent outbreaks in parts of West Africa. Ebola virus is currently one of the most deadly infectious agents in both non-human primates (NHPs) and humans [87]. The main target for the NAbs is EBOV is their glycoprotein (GP), and the need to eradicate this deadly virus in West Africa led to the development of the Ebola vaccine, which is currently under clinical trials. Two approaches were adopted to generate a vaccine:

(i) A combination of modified vaccinia virus Ankara (MVA-BN-Filo) and recombinant chimpanzee adenovirus $(\mathrm{rChAd} / \mathrm{EBOV})$ vaccine induce the immune system toward viruses, and $100 \%$ of macaques were protected against the Ebola infection following vaccination [88].

(ii) The expression of EBOV GP using a vesicular stomatitis virus also activates the production of antibodies. Here, non-human primates were protected against the virus after vaccination [89].

Among antiviral therapies in use presently to target filoviruses, NAbs seem to demonstrate the highest efficacy as a protective agent [90]. Study shows that the combination of three NAbs $(1 \mathrm{H} 3,2 \mathrm{G} 4$, and $4 \mathrm{G} 7)$ directly targeting the GP of the Ebola virus in cynomolgus macaques leads to complete survival with no visible side effects or perhaps full recovery [91, 92].

Unfortunately, until now, there is no licensed vaccine or any biological treatments available for EBOV in human use. However, in ongoing trials, mAbs targeting EBOV show great supportive care [93-95]. Recombinant vesicular stomatitis virus-Zaire Ebola virus (rVSV-ZEBOV) is an advanced Ebola virus vaccine candidate that was used as supportive care to fight the outbreak of Ebola virus disease in the Democratic Republic of the Congo [96].

ZMapp has been given to participants in a randomized control trial during the 2014 west Africa EBOV outbreak [97], while mAb114 is a monoclonal antibody that has been isolated from human survivor and successful targets (conserve epitopes in receptor-binding domain region of Ebola virus glycoprotein, which has shown promising results in the treatment of an Ebola outbreak). In the first human phase 1 study, mAb114 found to be safe and well-tolerated, which has been approved to use for an expanded access protocol of patients infected with the Ebola virus by the Democratic Republic of the Congo [98].

\section{NAbs against Chikungunya virus (CHIKV)}

Chikungunya virus is a type of mosquito-transmitted alphavirus that can cause acute or chronic polyarthritis and foot swelling [99]. CHIKV has genetically conserved envelope GPs (E1, E2, and E3). In acidified endosomes, low PH triggers conformational change, which allows the envelope GPs to engage in membrane fusion [100].

Antibodies block the entry of CHIKV to host cells by binding to $\mathrm{Fc} \gamma$ receptors of the host cell or binding to desired epitopes in CHIKV GPs. Previous trials in mice strain lacking $\mathrm{F} c \gamma$ receptors with engineered antibody confirmed the therapeutic effects of antibodies on the expression of $\mathrm{Fc} \gamma$ receptors [101]. Using antiCHIKV mAbs showed that the $\mathrm{Fc}$ region is critical for CHIKV infection during the acute phase of the disease and required for optimal protection against foot swelling. Combination therapy of two anti-CHIKV neutralizing mAbs [CHK-166 (anti-E1) and CHK-152 (anti-E2)] improved survival compared with single therapy of mAbs [102]. MAbs (5 M16, CHK-152) prevent the activation of membrane fusion of CHIKV through inhibition of conformational changes [103, 104]. Ultrapotent neutralizing human monoclonal antibodies (mAbs) have been isolated from the B cells of a survivor of natural CHIKV infection and encoded into mRNA vector. It has shown biologically significant levels in vivo after infusion of mRNAs in lipid nanoparticles [105]. 


\section{NAbs against Middle East respiratory syndrome coronavirus (MERS-CoV)}

$>$ Middle east respiratory syndrome coronavirus is a type of zoonotic viral pathogen that can cause fatal acute respiratory infections [106].

receptor-binding domain $(R B D)$ of envelope glycoprotein binds to the cell surface receptor dipeptidyl peptidase 4 (DPP4), which enables it to target host cells [107]. Using a combination of neutralizing antibodies like MERS-27 and MERS-4 synergistically increases the efficacy of neutralization against pseudotyped MERS-CoV [108]. This process reduces the viral infection in the lungs (90) [109]. Up to date, there is no licensed and approved treatment for MERS-CoV infections in humans. On the contrary, NAbs such as M336, LCA60, REGN3051, 311B-N1, and REGN3048 target MERS-CoV in transgenic mice and have exhibited tremendous preventive and therapeutic efficacy [110-112].

\section{NAbs against severe acute respiratory syndrome (SARS)}

Severe acute respiratory syndrome (SARS) belongs to the Coronavirus genus in the Coronaviridae family with positivesense RNA genomes. It is a type of zoonotic viral pathogen that causes acute respiratory infections [107, 113, 114].

Spike (S) protein of (SARS) is the main target for antibodies' neutralization $[115,116]$, which has two subunits Nterminal domain (NTD) and C-terminal domain (C-domain). Depends on the virus subtype, either NTD or C domain can serve as the receptor-binding domain $(R B D)$ [117]. Recent studies confirmed that human angiotensin-converting enzyme 2 (hACE2) is the main target receptor for the treatment of SARS infection [118].

80R immunoglobulin G1 (IgG1), a human mAb acts against (SARS-CoV) spike (S) protein, has led to inhibition of viral entry in vitro and was investigated in vivo in a mouse model which showed promising results as immunoprophylaxis agent [119]. Moreover, a combination of human mAbs (CR3014 and CR3022) have potentially neutralized SARS-CoV by targeting different epitopes on the receptor-binding domain of (S)protein [120].

To date, there is no licensed and approved treatment for SARS-CoV infections in humans. While recent studies confirmed (LCA60 mAb) inhibits binding to (hACE2) receptor, it has the potential to be active against SARS-CoV [121].

\section{NAbs against severe acute respiratory syndrome coronavirus 2 (SARS-CoV-2)}

Severe acute respiratory syndrome coronavirus 2 (SARS-CoV2) is a type of zoonotic pathogen belong Coronaviridae family (non-segmented positive-sense RNA viruses) has led to cause a newly emerged Coronavirus disease 2019 (COVID-19) with mild to moderate symptoms of respiratory disease [122-124].

The spike glycoprotein $(S)$ of coronavirus $(\mathrm{CoVs})$ is the main target for antibody neutralization, which has two subunits $\mathrm{N}$ terminal domain (NTD) and C-terminal domain (C-domain). Depends on the virus subtype, either NTD or C domain can serve as the receptor-binding domain (RBD) [117] [125].In the case of MERS-CoV and SARS-CoV subtype viruses, the receptors are human dipeptidyl peptidase 4 (hDPP4) [126] and human angiotensin-converting enzyme 2 ( $h A C E 2$ ) [118], respectively. Recent studies confirmed SARS-CoV2 uses the same cell entry receptor-angiotensin-converting enzyme II (ACE2) - as SARS-CoV [127, 128]; therefore, RBD in the S1 subunit of S protein contains the dominant neutralizing epitopes for inducing neutralizing antibodies [117, 129]. Moreover, the neutralizing mAbs against SARS-CoV RBD can be evaluated for significant efficacy against SARS-CoV-2 [130]. Neutralizing antibodies have potential activity against the receptor-binding domain $(R B D)$ in spike protein, or that can bind to the ACE2 receptor could show great results toward SARS-Cov-2 [131, 132].

Neutralizing mAbs against pro-inflammatory cytokines (IL1, IL-17, IL-6) may show significant effect against SARSCoV2 [133], as one clinical trial (ChiCTR2000029765), using tocilizumab (mAb), reported quick control of COVID-19 symptoms in 21 patients in Anhui, China [134].

COVID-19 infection has led to a global outbreak with morbidity and mortality. Although new investment in biomedical and pharmaceutical researches under ongoing development, using antiviral drug repurposing and other supportive therapies have shown promising results [135]. Up to date, either effective vaccines or neutralizing antibodies have been approved to target SARS-CoV-2. Currently, polyclonal antibodies isolated from recovered SARS-CoV-2-infected patients have been used to treat SARS-CoV-2 infection, but no specific neutralizing mAbs for SARS-CoV-2 have been reported [136]. Markedly, studies confirm RBD-specific human neutralizing $\mathrm{mAb}$ for SARS-CoV, CR3022 could bind to SARSCoV-2 RBD with high affinity $[137,138]$.

Furthermore, cocktails of RBD-specific antibodies and other regions in the $\mathrm{S}$ protein may further improve the potency of nAbs against SARS-CoV-2 and its escape-mutant strains. As well, scientists have tried human sera from convalescent patients to treat COVID-19 [136]. Recent research shows that the N terminal domain (NTD) of the S protein could also be a promising target for therapeutic mAbs against COVID-19 [139].

\section{Limitation of neutralizing antiviral antibodies}

Although mAbs might have remarkable therapeutic effects, their strong influence on public health would be attained by the complete eradication of viruses, which can be achieved by the development of vaccines that can produce antibodies to 
Table 2 Some neutralizing antiviral antibodies in clinical trials

\begin{tabular}{|c|c|c|c|c|c|}
\hline Antibody & Target & Indication & Company & $\begin{array}{l}\text { Clinical } \\
\text { phase }\end{array}$ & $\begin{array}{l}\text { ClinicalTrials.gov } \\
\text { Identifier }\end{array}$ \\
\hline Ibalizumab & $\mathrm{CD} 4$ & HIV infection & TaiMed Biologics USA Corp & Approved & $\begin{array}{l}\text { NCT02707861 } \\
\text { NCT02716675 } \\
\text { NCT02568215 }\end{array}$ \\
\hline $\begin{array}{l}\text { VRC01, } \\
\text { NIAID }\end{array}$ & CD4- of HIV gp120 & HIV infection & NIAID Vaccine Research Centre (VRC) & 2 & $\begin{array}{l}\text { NCT02664415 } \\
\text { NCT02588586 } \\
\text { NCT02850016 }\end{array}$ \\
\hline 3BNC117 & CD4- HIV-1 Env protein. & HIV infection & Rockefeller University & 2 & $\begin{array}{l}\text { NCT02446847 } \\
\text { NCT02511990 } \\
\text { NCT02825797 }\end{array}$ \\
\hline $10-1074$ & $\begin{array}{l}\text { V3-glycan supersite of HIV } \\
\text { gp120 }\end{array}$ & HIV infection & Rockefeller University & 1 & NCT02825797 \\
\hline $\begin{array}{l}\text { 4E10,2F5, } \\
2 \mathrm{G} 12\end{array}$ & gp41 & HIV infection & Rockefeller University & $1 / 2$ & NCT00219986 \\
\hline PRO 140 & CCR5 receptors & HIV infection & CytoDyn, Inc & $2 b / 3$ & NCT01272258 \\
\hline ZMapp & & Ebla infection & Public Health Agency of Canada, Defyrus & $2 / 3$ & NCT02389192 \\
\hline $\begin{array}{l}\text { MHAA4549A } \\
(39.29)\end{array}$ & Hemagglutinin influenza A & $\begin{array}{c}\text { influenza A } \\
\text { infection }\end{array}$ & Genentech, Inc & 2 & NCT02623322 \\
\hline VIS410 & Hemagglutinin (HA) & $\begin{array}{c}\text { influenza A } \\
\text { infection }\end{array}$ & Visterra, Inc & 2 & NCT02989194 \\
\hline CR6261 & $\begin{array}{l}\text { HA1/HA2 from } 1918 \mathrm{H} 1 \mathrm{~N} 1 \\
\text { influenza and H5N1 }\end{array}$ & $\begin{array}{l}\text { influenza } \\
\text { infection }\end{array}$ & $\begin{array}{l}\text { National Institute of Allergy and Infectious } \\
\text { Diseases (NIAID }\end{array}$ & 2 & NCT02371668 \\
\hline CR8020 & Hemagglutinin (HA) & $\begin{array}{l}\text { influenza A } \\
\text { infection }\end{array}$ & Crucell Holland B. V & 2 & NCT01938352 \\
\hline TCN-032 & the ectodomain of influenza A & $\begin{array}{c}\text { influenza A } \\
\text { infection }\end{array}$ & Theraclone Sciences & 2 & NCT01719874 \\
\hline
\end{tabular}

target specific epitopes on viruses [140-142]. Neutralizing antibodies (NAbs) are the foundation for controlling many infections and prevention as the most established vaccines. However, in the case of some viruses that can cause chronic infections such as HIV or HCV, the production of broad NAbs from recombinant antibody vaccines has still been elusive [17].

The development of mAbs as anti-infectious agents has been delayed due to scientific challenges, clinical trials, and market challenges. These challenges include viral variability and antigenic escape, shortage of treatable viral infections, high cost for production of recombinant antibodies, and competition with effective antiviral vaccines entering the market that could rapidly replace the need for passively infused mAbs. Another potential obstacle is the relatively short duration of viral illnesses, which makes them less attractive commercial targets than diseases such as cancer or chronic inflammatory or autoimmune diseases that require longer $\mathrm{mAb}$ treatment cycles. Also, it is expected that antiviral mAbs will not only be used but in combination with other drugs that inhibit post-entry steps of the virus life cycle [24, 30].

\section{Conclusion}

For successful infection control, virus-mediated antibody responses can promote long life surveillance and better protection from life-threatening infections.
The outstanding ability to separate and purify antigen and quickly determine the structural and functional effect of antibodies to target specific epitopes on viral envelope GP has dramatically increased our knowledge of the site of action of viruses.

Through many mechanisms, antibodies can protect host cells from viral infections and, moreover, alleviate the clinical symptoms and attenuate viral progression.

Antiviral antibodies mentioned in this review confirm their great potential as preventive and therapeutic agents against many viruses. Using various antibodies characterization approaches discussed here might lead to the more efficient production of neutralizing antibodies to continue providing crucial insights into how we can finally develop immunotherapeutic against pathogens that have thus far evaded our efforts. More precisely, the combination therapy of antiviral antibodies would expect to have broad and potent neutralizing activity against wild-type viruses. (Tables 1 and 2).

Acknowledgments This study was supported by grants from the National Natural Science Foundation of China (81973223); "Double First-Class" University project (CPU2018PZQ12 and CPU2018GY14). We thank George Frimpong Boafo, Dahiru Nasiru Sintali, and Umer Ejaz for their assistance in preparing the figures and also thank Ebenezer Kwame Adomako for the final draft of the report. 


\section{Compliance with ethical standards}

Conflict of interest All authors declare no competing interests.

\section{References}

1. Parkin J, Cohen BJTL. An overview of the immune system. Immunology. 2001;357(9270):1777-89.

2. Behring EV. About the development of diphtheria immunity and tetanus immunity in animals. Philipps-Universität Marburg. 1890.

3. Wang X-Y, Wang B, Wen Y-MJNV. From therapeutic antibodies to immune complex vaccines. NPJ Vaccines. 2019;4(1):2.

4. Rajewsky K. The advent and rise of monoclonal antibodies. Nature. 2019;575(7781):47-9.

5. McMichael AJ, et al. The immune response during acute HIV-1 infection: clues for vaccine development. Nat Rev Immunol. 2010;10(1):11.

6. Sekaly R-P. The failed HIV Merck vaccine study: a step back or a launching point for future vaccine development? J Exp Med. 2008;205(1):7-12.

7. Nachbagauer R, Krammer F. Universal influenza virus vaccines and therapeutic antibodies. Clin Microbiol Infect. 2017;23(4): $222-8$.

8. Brekke OH, Sandlie IJNrDd. Therapeutic antibodies for human diseases at the dawn of the twenty-first century. Nat Rev Drug Discov. 2003;2(1):52-62.

9. Walker LM, Burton DRJNRI. Passive immunotherapy of viral infections: 'super-antibodies' enter the fray. Nat Rev Immunol. 2018;18(5):297.

10. Excler JL, Ake J, Robb ML, Kim JH, Plotkin SA. Nonneutralizing functional antibodies: a new "old" paradigm for HIV vaccines. Clinical and Vaccine Immunology. 2014;21(8):1023-36.

11. Burton DR, Mascola JR. Antibody responses to envelope glycoproteins in HIV-1 infection. Nat Immunol. 2015;16(6):571.

12. Mayr LM, Su B, Moog C. Non-neutralizing antibodies directed against HIV and their functions. Front Immunol. 2017;8:1590.

13. Mayr LM, Decoville T, Schmidt S, Laumond G, Klingler J, Ducloy C, Bahram S, Zolla-Pazner S, Moog C. Nonneutralizing antibodies targeting the V1V2 domain of HIV exhibit strong antibody-dependent cell-mediated cytotoxic activity. Sci Rep. 2017;7(1):1.

14. Chan AC, Carter PJJNRI. Therapeutic antibodies for autoimmunity and inflammation. Nat Rev Immunol. 2010;10(5):301-16.

15. Sparrow E, Friede M, Sheikh M, Torvaldsen S. Therapeutic antibodies for infectious diseases. Bulletin of the World Health Organization. 2017;95(3):235.

16. Murin $\mathrm{CD}$, Wilson IA, Ward AB. Antibody responses to viral infections: a structural perspective across three different enveloped viruses. Nat Microbiol. 2019;1.

17. Garrone P, Fluckiger AC, Mangeot PE, Gauthier E, DupeyrotLacas P, Mancip J, Cangialosi A, Du Chéné I, LeGrand R, Mangeot I, Lavillette D. A prime-boost strategy using virus-like particles pseudotyped for HCV proteins triggers broadly neutralizing antibodies in macaques. Sci Transl Med. 2011;3(94):94ra71.

18. Mascola JR, Montefiori DCJAroi. The role of antibodies in HIV vaccines. Annu Rev Immunol. 2009;28:413-44.

19. Koff WC, Burton DR, Johnson PR, Walker BD, King CR, Nabel GJ, Ahmed R, Bhan MK, Plotkin SA. Accelerating nextgeneration vaccine development for global disease prevention. Science. 2013;340:(6136).

20. Krause PR, Bialek SR, Boppana SB, Griffiths PD, Laughlin CA, Ljungman P, Mocarski ES, Pass RF, Read JS, Schleiss MR,
Plotkin SA. Priorities for CMV vaccine development. Vaccine. 2013;32(1):4-10.

21. Saylor C, Dadachova E, Casadevall A. Monoclonal antibodybased therapies for microbial diseases. Vaccine. 2009;27:G38-46.

22. Klein C. Monoclonal Antibodies. Multidisciplinary Digital Publishing Institute MDPI; Antibodies. 2018;7(2).

23. Campoli M, Ferris R, Ferrone S, Wang X. Immunotherapy of malignant disease with tumor antigen-specific monoclonal antibodies. Clin Cancer Res. 2010;16(1):11-20.

24. Marasco WA, Sui J. The growth and potential of human antiviral monoclonal antibody therapeutics. Nat Biotechnol. 2007;25(12): 1421-34.

25. Haurum JS. Recombinant polyclonal antibodies: the next generation of antibody therapeutics? Drug Discov Today. 2006;11(1314):655-60.

26. Stills HF. Polyclonal antibody production. InThe Laboratory Rabbit, Guinea Pig, Hamster, and Other Rodents. Academic Press. 2012;(pp. 259-274).

27. Wilson PC, Andrews SF. Tools to therapeutically harness the human antibody response. Nat Rev Immun. 2012;12(10):709-19.

28. Hammers CM, Stanley JR. Antibody phage display: technique and applications. The J Invest Dermatol. 2014;134(2):e17.

29. Bowley DR, Labrijn AF, Zwick MB, Burton DR. Antigen selection from an HIV-1 immune antibody library displayed on yeast yields many novel antibodies compared to selection from the same library displayed on phage. Protein Eng Des Sel. 2007;20(2):8190.

30. Salazar G, Zhang N, Fu TM, An Z. Antibody therapies for the prevention and treatment of viral infections. npj Vaccines. 2017;2(1):1-2.

31. Gao L, Jiang Y, Mu L, Liu Y, Wang F, Wang P, Zhang A, Tang N, Chen T, Luo M, Yu L. Efficient generation of mice with consistent transgene expression by FEEST. Sci Rep. 2015;5:16284.

32. Meng W, Pan W, Zhang AJ, Li Z, Wei G, Feng L, Dong Z, Li C, $\mathrm{Hu} X$, Sun C, Luo Q. Rapid generation of human-like neutralizing monoclonal antibodies in urgent preparedness for influenza pandemics and virulent infectious diseases. PLoS One. 2013;8(6): e66276.

33. Bernasconi NL, Traggiai E, Lanzavecchia A. Maintenance of serological memory by polyclonal activation of human memory B cells. Science. 2002;298(5601):2199-202.

34. Warter L, Lee CY, Thiagarajan R, Grandadam M, Lebecque S, Lin RT, Bertin-Maghit $\mathrm{S}, \mathrm{Ng}$ LF, Abastado JP, Desprès $\mathrm{P}$, Wang CI. Chikungunya virus envelope-specific human monoclonal antibodies with broad neutralization potency. The Journal of Immunology. 2011;186(5):3258-64.

35. Corti D, Suguitan AL, Pinna D, Silacci C, Fernandez-Rodriguez BM, Vanzetta F, Santos C, Luke CJ, Torres-Velez FJ, Temperton NJ, Weiss RA. Heterosubtypic neutralizing antibodies are produced by individuals immunized with a seasonal influenza vaccine. J Clin Investig. 2010;120(5):1663-73.

36. Tiller T. Single B cell antibody technologies. New Biotechnol. 2011;28(5):453-7.

37. Dejnirattisai W, Wongwiwat W, Supasa S, Zhang X, Dai X, Rouvinski A, Jumnainsong A, Edwards C, Quyen NT, Duangchinda T, Grimes JM. A new class of highly potent, broadly neutralizing antibodies isolated from viremic patients infected with dengue virus. Nat Immunol. 2015;16(2):170-7.

38. Wrammert J, Smith K, Miller J, Langley WA, Kokko K, Larsen C, Zheng NY, Mays I, Garman L, Helms C, James J. Rapid cloning of high-affinity human monoclonal antibodies against influenza virus. Nature. 2008;453(7195):667-71.

39. Wrammert J, Koutsonanos D, Li GM, Edupuganti S, Sui J, Morrissey M, McCausland M, Skountzou I, Hornig M, Lipkin WI, Mehta A. Broadly cross-reactive antibodies dominate the 
human B cell response against 2009 pandemic H1N1 influenza virus infection. J Exp Med. 2011;208(1):181-93.

40. Meng W, Li L, Xiong W, Fan X, Deng H, Bett AJ, Chen Z, Tang A, Cox KS, Joyce JG, Freed DC. Efficient generation of monoclonal antibodies from single rhesus macaque antibody secreting cells. InMAbs,Taylor \& Francis. 2015 Jul 4 (Vol. 7, No. 4, pp. 707-718).

41. Sloan SE, Hanlon C, Weldon W, Niezgoda M, Blanton J, Self J, Rowley KJ, Mandell RB, Babcock GJ, Thomas WD Jr, Rupprecht $\mathrm{CE}$. Identification and characterization of a human monoclonal antibody that potently neutralizes a broad panel of rabies virus isolates. Vaccine. 2007;25(15):2800-10.

42. Coughlin M, Lou G, Martinez O, Masterman SK, Olsen OA, Moksa AA, Farzan M, Babcook JS, Prabhakar BS. Generation and characterization of human monoclonal neutralizing antibodies with distinct binding and sequence features against SARS coronavirus using XenoMouse®. Virology. 2007;361(1):93-102.

43. Traggiai E, Becker S, Subbarao K, Kolesnikova L, Uematsu Y, Gismondo MR, Murphy BR, Rappuoli R, Lanzavecchia A. An efficient method to make human monoclonal antibodies from memory B cells: potent neutralization of SARS coronavirus. Nat Med. 2004;10(8):871-5.

44. Sundling C, Phad G, Douagi I, Navis M, Hedestam GB. Isolation of antibody V (D) J sequences from single cell sorted rhesus macaque B cells. J Immunol Methods. 2012;386(1-2):85-93.

45. Demberg T, Brocca-Cofano E, Xiao P, Venzon D, VargasInchaustegui D, Lee EM, Kalisz I, Kalyanaraman VS, DiPasquale J, McKinnon K, Robert-Guroff M. Dynamics of memory B-cell populations in blood, lymph nodes, and bone marrow during antiretroviral therapy and envelope boosting in simian immunodeficiency virus SIVmac251-infected rhesus macaques. J Virol. 2012;86(23):12591-604.

46. Köhler G, Milstein C. Continuous cultures of fused cells secreting antibody of predefined specificity. Nature. 1975;256(5517):495-7.

47. DANIELS CA. Mechanisms of viral neutralization. InViral immunology and immunopathology. Elsevier: Academic Press; 1975. p. 79-97.

48. Klasse PJ. Neutralization of virus infectivity by antibodies: old problems in new perspectives. Advances in biology. 2014;2014

49. Earp LJ, Delos SE, Park HE, White JM. The many mechanisms of viral membrane fusion proteins. InMembrane trafficking in viral replication. Berlin, Heidelberg: Springer; 2004. p. 25-66.

50. White JM, Delos SE, Brecher M, Schornberg K. Structures and mechanisms of viral membrane fusion proteins: multiple variations on a common theme. Crit Rev in Biochem Mol. 2008;43(3):189-219.

51. Both L, Banyard AC, van Dolleweerd C, Wright E, Ma JK, Fooks AR. Monoclonal antibodies for prophylactic and therapeutic use against viral infections. Vaccine. 2013;31(12):1553-9.

52. E Ackerman M, Alter G. Opportunities to exploit non-neutralizing HIV-specific antibody activity. Current HIV research. 2013;11(5): 365-77.

53. Lu LL, Suscovich TJ, Fortune SM, Alter G. Beyond binding: antibody effector functions in infectious diseases. Nat Rev Immunol. 2018;18(1):46.

54. Julien JP, Wardemann H. Antibodies against Plasmodium falciparum malaria at the molecular level. Nat Rev Immunol. 2019;28:1-5.

55. Bregenholt S, Jensen A, Lantto J, Hyldig S, Haurum JS. Recombinant human polyclonal antibodies: a new class of therapeutic antibodies against viral infections. Curr Pharma Des. 2006;12(16):2007-15.

56. Shaw ML. The next wave of influenza drugs. ACS Infec Dis. 2017;3(10):691-4.
57. Miner JJ, Cook LE, Hong JP, Smith AM, Richner JM, Shimak RM, Young AR, Monte K, Poddar S, Crowe JE, Lenschow DJ. Therapy with CTLA4-Ig and an antiviral monoclonal antibody controls chikungunya virus arthritis. Sci Transl Med. 2017;9(375).

58. De Jong YP, Dorner M, Mommersteeg MC, Xiao JW, Balazs AB, Robbins JB, Winer BY, Gerges S, Vega K, Labitt RN, Donovan BM. Broadly neutralizing antibodies abrogate established hepatitis C virus infection. Sci Transl Med. 2014;6(254):254ra129.

59. Caskey M, Klein F, Nussenzweig MC. Broadly neutralizing antiHIV-1 monoclonal antibodies in the clinic. Nat Med. 2019;25(4): 547-53.

60. Schoofs T, Klein F, Braunschweig M, Kreider EF, Feldmann A, Nogueira L, Oliveira T, Lorenzi JC, Parrish EH, Learn GH, West AP. HIV-1 therapy with monoclonal antibody 3BNC117 elicits host immune responses against HIV-1. Science. 2016;352(6288): 997-1001.

61. Smith SA, Silva LA, Fox JM, Flyak AI, Kose N, Sapparapu G, Khomandiak S, Ashbrook AW, Kahle KM, Fong RH, Swayne S. Isolation and characterization of broad and ultrapotent human monoclonal antibodies with therapeutic activity against chikungunya virus. Cell Host Microbe. 2015;18(1):86-95.

62. Tahara M, Ito Y, Brindley MA, Ma X, He J, Xu S, Fukuhara H, Sakai K, Komase K, Rota PA, Plemper RK. Functional and structural characterization of neutralizing epitopes of measles virus hemagglutinin protein. J Virol. 2013;87(1):666-75.

63. Burton DR. What are the most powerful immunogen design vaccine strategies? Reverse vaccinology 2.0 shows great promise. Cold Spring Harb Perspect Biol. 2017;9(11):a030262.

64. Andrews SF, Huang Y, Kaur K, Popova LI, Ho IY, Pauli NT, Dunand CJ, Taylor WM, Lim S, Huang M, Qu X. Immune history profoundly affects broadly protective $\mathrm{B}$ cell responses to influenza. Sci Transl Med. 2015;7(316):316ra192.

65. Sather DN, Armann J, Ching LK, Mavrantoni A, Sellhorn G, Caldwell Z, Yu X, Wood B, Self S, Kalams S, Stamatatos L. Factors associated with the development of cross-reactive neutralizing antibodies during human immunodeficiency virus type 1 infection. J Virol. 2009;83(2):757-69.

66. Casadevall A, Scharff MD. Return to the past: the case for antibody-based therapies in infectious diseases. Clin Infec Dis. 1995;21(1):150-61.

67. Czajkowsky DM, Hu J, Shao Z, Pleass RJ. Fc-fusion proteins: new developments and future perspectives. EMBO Mol Med. 2012;4(10):1015-28.

68. Gautam R, Nishimura Y, Gaughan N, Gazumyan A, Schoofs T, Buckler-White A, Seaman MS, Swihart BJ, Follmann DA, Nussenzweig MC, Martin MA. A single injection of crystallizable fragment domain-modified antibodies elicits durable protection from SHIV infection. Nat Med. 2018;24(5):610-6.

69. Walker LM, Huber M, Doores KJ, Falkowska E, Pejchal R, Julien JP, Wang SK, Ramos A, Chan-Hui PY, Moyle M, Mitcham JL. Broad neutralization coverage of HIV by multiple highly potent antibodies. Nature. 2011;477(7365):466-70.

70. Walker LM, Phogat SK, Chan-Hui PY, Wagner D, Phung P, Goss JL, Wrin T, Simek MD, Fling S, Mitcham JL, Lehrman JK. Broad and potent neutralizing antibodies from an African donor reveal a new HIV-1 vaccine target. Science. 2009;326(5950):285-9.

71. Wu X, Yang ZY, Li Y, Hogerkorp CM, Schief WR, Seaman MS, Zhou T, Schmidt SD, Wu L, Xu L, Longo NS. Rational design of envelope identifies broadly neutralizing human monoclonal antibodies to HIV-1. Science. 2010;329(5993):856-61.

72. Burton DR, Hangartner L. Broadly neutralizing antibodies to HIV and their role in vaccine design. Annu Rev Immunol. 2016;34: $635-59$. 
73. Doria-Rose NA, Klein RM, Daniels MG, O’Dell S, Nason M, Lapedes A, Bhattacharya T, Migueles SA, Wyatt RT, Korber BT, Mascola JR. Breadth of human immunodeficiency virusspecific neutralizing activity in sera: clustering analysis and association with clinical variables. J Virol. 2010;84(3):1631-6.

74. Euler Z, van Gils MJ, Bunnik EM, Phung P, Schweighardt B, Wrin T, Schuitemaker H. Cross-reactive neutralizing humoral immunity does not protect from HIV type 1 disease progression. J Infect Dis. 2010;201(7):1045-53.

75. Freund NT, Wang H, Scharf L, Nogueira L, Horwitz JA, Bar-On Y, Golijanin J, Sievers SA, Sok D, Cai H, Lorenzi JC. Coexistence of potent HIV-1 broadly neutralizing antibodies and antibodysensitive viruses in a viremic controller. Sci Transl Med. 2017;9(373).

76. Liao HX, Lynch R, Zhou T, Gao F, Alam SM, Boyd SD, Fire AZ, Roskin KM, Schramm CA, Zhang Z, Zhu J. Co-evolution of a broadly neutralizing HIV-1 antibody and founder virus. Nature. 2013;496(7446):469-76.

77. Scheid JF, Mouquet H, Ueberheide B, Diskin R, Klein F, Oliveira TY, Pietzsch J, Fenyo D, Abadir A, Velinzon K, Hurley A. Sequence and structural convergence of broad and potent HIV antibodies that mimic CD4 binding. Science. 2011;333(6049): 1633-7.

78. Han Q, Jones JA, Nicely NI, Reed RK, Shen X, Mansouri K, Louder M, Trama AM, Alam SM, Edwards RJ, Bonsignori M. Difficult-to-neutralize global HIV-1 isolates are neutralized by antibodies targeting open envelope conformations. Nat Commun. 2019;10(1):1-5.

79. Shingai M, Donau OK, Plishka RJ, Buckler-White A, Mascola JR, Nabel GJ, Nason MC, Montefiori D, Moldt B, Poignard P, Diskin R. Passive transfer of modest titers of potent and broadly neutralizing anti-HIV monoclonal antibodies block SHIV infection in macaques. J Exp Med. 2014;211(10):2061-74.

80. Julg B, Tartaglia LJ, Keele BF, Wagh K, Pegu A, Sok D, Abbink P, Schmidt SD, Wang K, Chen X, Joyce MG. Broadly neutralizing antibodies targeting the HIV-1 envelope V2 apex confer protection against a clade C SHIV challenge. Sci Transl Med. 2017;9(406).

81. Molinos-Albert LM, Clotet B, Blanco J, Carrillo J. Immunologic insights on the membrane proximal external region: a major human immunodeficiency virus type- 1 vaccine target. Front Immun. 2017;8:1154.

82. DiLillo DJ, Tan GS, Palese P, Ravetch JV. Broadly neutralizing hemagglutinin stalk-specific antibodies require Fc $\gamma \mathrm{R}$ interactions for protection against influenza virus in vivo. Nat Med. 2014;20(2):143-51.

83. Bournazos S, Klein F, Pietzsch J, Seaman MS, Nussenzweig MC, Ravetch JV. Broadly neutralizing anti-HIV-1 antibodies require Fc effector functions for in vivo activity. Cell. 2014;158(6): 1243-53.

84. Lu CL, Murakowski DK, Bournazos S, Schoofs T, Sarkar D, Halper-Stromberg A, Horwitz JA, Nogueira L, Golijanin J, Gazumyan A, Ravetch JV. Enhanced clearance of HIV-1-infected cells by broadly neutralizing antibodies against HIV-1 in vivo. Science. 2016;352(6288):1001-4.

85. Caskey M, Klein F, Lorenzi JC, Seaman MS, West AP, Buckley N, Kremer G, Nogueira L, Braunschweig M, Scheid JF, Horwitz JA. Viraemia suppressed in HIV-1-infected humans by broadly neutralizing antibody 3BNC117. Nature. 2015;522(7557):487-91.

86. Serra-Peinado C, Grau-Expósito J, Luque-Ballesteros L, AstorgaGamaza A, Navarro J, Gallego-Rodriguez J, Martin M, Curran A, Burgos J, Ribera E, Raventós B. Expression of CD20 after viral reactivation renders HIV-reservoir cells susceptible to rituximab. Nat Commun. 2019;10(1):1-5.
87. Hartman AL, Towner JS, Nichol ST. Ebola and marburg hemorrhagic fever. Clinics in Laboratory Medicine. 2010;30(1):161-77.

88. Qiu X, Audet J, Wong G, Pillet S, Bello A, Cabral T, Strong JE, Plummer F, Corbett CR, Alimonti JB, Kobinger GP. Successful treatment of Ebola virus-infected cynomolgus macaques with monoclonal antibodies. Sci Transl Med. 2012;4(138):138ra81.

89. Stanley DA, Honko AN, Asiedu C, Trefry JC, Lau-Kilby AW, Johnson JC, Hensley L, Ammendola V, Abbate A, Grazioli F, Foulds KE. Chimpanzee adenovirus vaccine generates acute and durable protective immunity against ebolavirus challenge. Nat Med. 2014;20(10):1126-9.

90. Marzi A, Robertson SJ, Haddock E, Feldmann F, Hanley PW, Scott DP, Strong JE, Kobinger G, Best SM, Feldmann H. VSVEBOV rapidly protects macaques against infection with the 2014/ 15 Ebola virus outbreak strain. Science. 2015;349(6249):739-42.

91. Hiatt A, Zeitlin L, Whaley K, Pauly M, inventors. Monoclonal antibody cocktails for treatment of ebola infections. Google Patents, Mapp Biopharmaceutical, Inc., assignee. 2016.

92. Bornholdt ZA, Turner HL, Murin CD, Li W, Sok D, Souders CA, Piper AE, Goff A, Shamblin JD, Wollen SE, Sprague TR. Isolation of potent neutralizing antibodies from a survivor of the 2014 Ebola virus outbreak. Science. 2016;351(6277):1078-83.

93. Cross RW, Mire CE, Feldmann H, Geisbert TW. Post-exposure treatments for Ebola and Marburg virus infections. Nat Rev Drug Discov. 2018;17(6):413-34.

94. Hernandez-Vargas EA. Windows of opportunity for Ebola virus infection treatment and vaccination. Sci Rep. 2017;7(1):1-0.

95. Qiu X, Wong G, Audet J, Bello A, Fernando L, Alimonti JB, Fausther-Bovendo H, Wei H, Aviles J, Hiatt E, Johnson A. Reversion of advanced Ebola virus disease in nonhuman primates with ZMapp. Nature. 2014;514(7520):47-53.

96. Madelain V, Nguyen TH, Olivo A, De Lamballerie X, Guedj J, Taburet AM, Mentré F. Ebola virus infection: review of the pharmacokinetic and pharmacodynamic properties of drugs considered for testing in human efficacy trials. Clin Pharmacokinet. 2016;55(8):907-23.

97. Group TP, Multi-National PREVAIL II Study Team. A randomized, controlled trial of ZMapp for Ebola virus infection. New Engl J Med. 2016;375(15):1448.

98. Gaudinski MR, Coates EE, Novik L, Widge A, Houser KV, Burch E, Holman LA, Gordon IJ, Chen GL, Carter C, Nason M. Safety, tolerability, pharmacokinetics, and immunogenicity of the therapeutic monoclonal antibody mAb114 targeting Ebola virus glycoprotein (VRC 608): an open-label phase 1 study. The Lancet. 2019;393(10174):889-98.

99. Ehrhardt SA, Zehner M, Krähling V, Cohen-Dvashi H, Kreer C, Elad N, Gruell H, Ercanoglu MS, Schommers P, Gieselmann L, Eggeling R. Polyclonal and convergent antibody response to Ebola virus vaccine rVSV-ZEBOV. Nat Med. 2019;25(10): 1589-600.

100. Ross RW. The Newala epidemic: III. The virus: isolation, pathogenic properties and relationship to the epidemic. Epidemiol Infect. 1956;54(2):177-91.

101. Jin J, Simmons G. Antiviral functions of monoclonal antibodies against chikungunya virus. Viruses. 2019;11(4):305.

102. Fox JM, Roy V, Gunn BM, Huang L, Edeling MA, Mack M, Fremont DH, Doranz BJ, Johnson S, Alter G, Diamond MS. Optimal therapeutic activity of monoclonal antibodies against chikungunya virus requires $\mathrm{Fc}-\mathrm{Fc} \gamma \mathrm{R}$ interaction on monocytes. Sci Immunol. 2019;4(32).

103. Pal P, Dowd KA, Brien JD, Edeling MA, Gorlatov S, Johnson S, Lee I, Akahata W, Nabel GJ, Richter MK, Smit JM. Development of a highly protective combination monoclonal antibody therapy against Chikungunya virus. PLoS Pathog. 2013;9(4):e1003312. 
104. Sun S, Xiang Y, Akahata W, Holdaway H, Pal P, Zhang X, Diamond MS, Nabel GJ, Rossmann MG. Structural analyses at pseudo atomic resolution of Chikungunya virus and antibodies show mechanisms of neutralization. Elife. 2013;2:e00435.

105. Kose N, Fox JM, Sapparapu G, Bombardi R, Tennekoon RN, De Silva AD, Elbashir SM, Theisen MA, Humphris-Narayanan E, Ciaramella G, Himansu S. A lipid-encapsulated mRNA encoding a potently neutralizing human monoclonal antibody protects against chikungunya infection. Scie Immunol. 2019;4(35).

106. Long F, Fong RH, Austin SK, Chen Z, Klose T, Fokine A, Liu Y, Porta J, Sapparapu G, Akahata W, Doranz BJ. Cryo-EM structures elucidate neutralizing mechanisms of anti-chikungunya human monoclonal antibodies with therapeutic activity. Proceedings of the National Academy of Sciences. 2015;112(45):13898-903.

107. De Wit E, Van Doremalen N, Falzarano D, Munster VJ. SARS and MERS: recent insights into emerging coronaviruses. Nat Rev Microbiol. 2016;14(8):523.

108. Wang N, Shi X, Jiang L, Zhang S, Wang D, Tong P, Guo D, Fu L, Cui Y, Liu X, Arledge KC. Structure of MERS-CoV spike receptor-binding domain complexed with human receptor DPP4. Cell Research. 2013;23(8):986-93.

109. Jiang L, Wang N, Zuo T, Shi X, Poon KM, Wu Y, Gao F, Li D, Wang R, Guo J, Fu L. Potent neutralization of MERS-CoV by human neutralizing monoclonal antibodies to the viral spike glycoprotein. Sci Transl Med. 2014;6(234):234ra59.

110. Luke T, Wu H, Zhao J, Channappanavar R, Coleman CM, Jiao JA, Matsushita H, Liu Y, Postnikova EN, Ork BL, Glenn G. Human polyclonal immunoglobulin $\mathrm{G}$ from transchromosomic bovines inhibits MERS-CoV in vivo. Sci Transl Med. 2016;8(326):326ra21.

111. Pascal KE, Coleman CM, Mujica AO, Kamat V, Badithe A, Fairhurst J, Hunt C, Strein J, Berrebi A, Sisk JM, Matthews KL. Pre-and postexposure efficacy of fully human antibodies against Spike protein in a novel humanized mouse model of MERS-CoV infection. Proceedings of the National Academy of Sciences. 2015;112(28):8738-43.

112. Corti D, Zhao J, Pedotti M, Simonelli L, Agnihothram S, Fett C, Fernandez-Rodriguez B, Foglierini M, Agatic G, Vanzetta F, Gopal R. Prophylactic and postexposure efficacy of a potent human monoclonal antibody against MERS coronavirus. Proceedings of the National Academy of Sciences. 2015;112(33):10473-8.

113. Fouchier RA, Kuiken T, Schutten M, Van Amerongen G, Van Doornum GJ, Van Den Hoogen BG, Peiris M, Lim W, Stöhr K, Osterhaus AD. Koch's postulates fulfilled for SARS virus. Nature. 2003;423(6937):240.

114. Peiris JS, Lai ST, Poon LL, Guan Y, Yam LY, Lim W, Nicholls J, Yee WK, Yan WW, Cheung MT, Cheng VC. Coronavirus as a possible cause of severe acute respiratory syndrome. The Lancet. 2003;361(9366):1319-25.

115. Gallagher TM, Buchmeier MJ. Coronavirus spike proteins in viral entry and pathogenesis. Virology. 2001;279(2):371-4.

116. Holmes KV. SARS-associated coronavirus. New England Journal of Medicine. 2003;348(20):1948-51.

117. Ou X, Liu Y, Lei X, Li P, Mi D, Ren L, Guo L, Guo R, Chen T, Hu $\mathrm{J}$, Xiang Z. Characterization of spike glycoprotein of SARS-CoV2 on virus entry and its immune cross-reactivity with SARS-CoV. Nat Commun. 2020;11(1):1-2.

118. Li W, Moore MJ, Vasilieva N, Sui J, Wong SK, Berne MA, Somasundaran M, Sullivan JL, Luzuriaga K, Greenough TC, Choe $\mathrm{H}$. Angiotensin-converting enzyme 2 is a functional receptor for the SARS coronavirus. Nature. 2003;426(6965):450-4.

119. Sui J, Li W, Roberts A, Matthews LJ, Murakami A, Vogel L, Wong SK, Subbarao K, Farzan M, Marasco WA. Evaluation of human monoclonal antibody $80 \mathrm{R}$ for immunoprophylaxis of severe acute respiratory syndrome by an animal study, epitope mapping, and analysis of spike variants. J Virol. 2005;79(10): 5900-6.

120. Ter Meulen J, Van Den Brink EN, Poon LL, Marissen WE, Leung CS, Cox F, Cheung CY, Bakker AQ, Bogaards JA, Van Deventer E, Preiser W. Human monoclonal antibody combination against SARS coronavirus: synergy and coverage of escape mutants. PLoS Med. 2006;3(7):e237.

121. Walls AC, Xiong X, Park YJ, Tortorici MA, Snijder J, Quispe J, Cameroni E, Gopal R, Dai M, Lanzavecchia A, Zambon M. Unexpected receptor functional mimicry elucidates activation of coronavirus fusion. Cell. 2019;176(5):1026-39.

122. Huang C, Wang Y, Li X, Ren L, Zhao J, Hu Y, Zhang L, Fan G, $\mathrm{Xu}$ J, Gu X, Cheng Z. Clinical features of patients infected with 2019 novel coronavirus in Wuhan, China. The Lancet. 2020;395(10223):497-506.

123. Xu Z, Shi L, Wang Y, Zhang J, Huang L, Zhang C, Liu S, Zhao P, Liu H, Zhu L, Tai Y. Pathological findings of COVID-19 associated with acute respiratory distress syndrome. Lancet Respir Med. 2020;8(4):420-2.

124. Richman DD, Whitley RJ, Hayden FG. Viral infections of the central nervous system. Clinical virology: John Wiley \& Sons; 2016.

125. Jiang S, Du L, Shi Z. An emerging coronavirus causing pneumonia outbreak in Wuhan, China: calling for developing therapeutic and prophylactic strategies. Emerg Microbes Infect. 2020;9(1): 275-7.

126. Raj VS, Mou H, Smits SL, Dekkers DH, Müller MA, Dijkman R, Muth D, Demmers JA, Zaki A, Fouchier RA, Thiel V. Dipeptidyl peptidase 4 is a functional receptor for the emerging human coronavirus-EMC. Nature. 2013;495(7440):251-4.

127. Zhou P, Yang XL, Wang XG, Hu B, Zhang L, Zhang W, Si HR, Zhu Y, Li B, Huang CL, Chen HD. A pneumonia outbreak associated with a new coronavirus of probable bat origin. Nature. 2020;579(7798):270-3.

128. Wan Y, Shang J, Graham R, Baric RS, Li F. Receptor recognition by the novel coronavirus from Wuhan: an analysis based on decade-long structural studies of SARS coronavirus. J Virol. 2020;94(7).

129. Jiang S, He Y, Liu S. SARS vaccine development. Emerging Infec Dis. 2005;11(7):1016.

130. Dhama K, Sharun K, Tiwari R, Dadar M, Malik YS, Singh KP, Chaicumpa W. COVID-19, an emerging coronavirus infection: advances and prospects in designing and developing vaccines, immunotherapeutics, and therapeutics. Human Vaccines \& Immunotherapeutics. 2020:1-7.

131. Shanmugaraj B, Siriwattananon K, Wangkanont K, Phoolcharoen W. Perspectives on monoclonal antibody therapy as potential therapeutic intervention for Coronavirus disease-19 (COVID-19). Asian Pac J Allergy Immunol. 2020;38(1):10-8.

132. Ibarrondo FJ, Fulcher JA, Goodman-Meza D, Elliott J, Hofmann C, Hausner MA, Ferbas KG, Tobin NH, Aldrovandi GM, Yang OO. Rapid decay of anti-SARS-CoV-2 antibodies in persons with mild Covid-19. N Engl J Med. 2020;383(11):1085-7.

133. Tan M, Liu Y, Zhou R, Deng X, Li F, Liang K, Shi Y. Immunopathological characteristics of coronavirus disease 2019 cases in Guangzhou, China. Immunology. 2020 May 27.

134. Cao X. COVID-19: immunopathology and its implications for therapy. Nat Rev Immunol. 2020;20(5):269-70.

135. Zhou Y, Hou Y, Shen J, Huang Y, Martin W, Cheng F. Networkbased drug repurposing for novel coronavirus 2019-nCoV/SARSCoV-2. Cell Discovery. 2020;6(1):1-8.

136. Jiang $\mathrm{S}$, Hillyer $\mathrm{C}, \mathrm{Du} \mathrm{L}$. Neutralizing antibodies against SARSCoV-2 and other human coronaviruses. Trends in immunology. 2020. 
137. Tian X, Li C, Huang A, Xia S, Lu S, Shi Z, Lu L, Jiang S, Yang Z, $\mathrm{Wu}$ Y, Ying T. Potent binding of 2019 novel coronavirus spike protein by a SARS coronavirus-specific human monoclonal antibody. Emerg Microbes Infect. 2020;9(1):382-5.

138. Rogers TF, Zhao F, Huang D, Beutler N, Burns A, He WT, Limbo O, Smith C, Song G, Woehl J, Yang L. Isolation of potent SARS$\mathrm{CoV}-2$ neutralizing antibodies and protection from disease in a small animal model. Science. 2020;369(6506):956-63.

139. Chi X, Yan R, Zhang J, Zhang G, Zhang Y, Hao M, Zhang Z, Fan $\mathrm{P}$, Dong Y, Yang Y, Chen Z. A neutralizing human antibody binds to the N-terminal domain of the Spike protein of SARS-CoV-2. Science. 2020;369(6504):650-5.
140. Kaur K, Sullivan M, Wilson PC. Targeting B cell responses in universal influenza vaccine design. Trends Immunol. 2011;32(11):524-31.

141. Moir S, Malaspina A, Fauci AS. Prospects for an HIV vaccine: leading B cells down the right path. Nat Struct Mol Biol. 2011;18(12):1317-21.

142. Kaminski DA, Lee FE. Antibodies against conserved antigens provide opportunities for reform in influenza vaccine design. Front Immunol. 2011;2.

Publisher's note Springer Nature remains neutral with regard to jurisdictional claims in published maps and institutional affiliations. 